Double-talk at USDA

The US Government must be both resolute and guileful to make sense of agricultural research.

THE remarkable thing about the failure of the US Department of Agriculture (USDA) to change the way it supports research is that nobody will come right out against competitive research grants. Representative Jamie Whitten, chairman of the House Appropriations Committee, member of Congress for 43 years and staunch defender of the time-honoured practice of doling out research funds to each state's land-grant university regardless of scientific merit (a practice that not coincidentally props up research institutions in Mr Whitten's home state of Mississippi), swears he is not against competitive grants - even as his committee cuts the heart out of that already enfeebled programme. If $\mathrm{Mr}$ Whitten gets his way, it will be $\$ 7$ million poorer than last year. (It has never crept above $\$ 17$ million, a dwarf by comparison with the almost $\$ 2,000$ million that the federal government and the states spend altogether on agricultural research.) The directors of the state experiment stations at the land-grant universities also swear they are not against competitive grants - even as they stage a campaign to force out the White House of ficial who dared to convene a workshop on agricultural research and dared to conclude that any new research funds should go to competitive grants. And, now, the new administrator of USDA's Cooperative State Research Service, the agency that administers the land-grants' research funds, says that he, too, is not against competitive grants. Only he, for one, is not dissembling.

Indeed, there is good reason to take Dr John P. Jordan at his word when he says much more money is needed for competitive peer-reviewed research grants for agriculture. Dr Jordan was most recently director of the Colorado experiment station. He is a $\mathrm{PhD}$ biochemist whose own laboratory depended heavily on competitive grants from outside USDA (both the National Science Foundation and the National Institutes of Health support more basic plant molecular biology research than does USDA). Thus he is well able to appreciate the changes that have lately taken place (not for the better) in agricultural research. "The storehouse of basic knowledge has been depleted", he says, and competitive, peer-reviewed grants will have a big part to play in restoring scientific expertise and prestige to agriculture. Dr Jordan sees his own appointment as a sign that USDA is serious about science and about increasing support for competitive grants. This, together with the establishment of a separate office for competitive grants and the creation of an assistant secretary of agriculture in charge of science, have, he says, "set the stage" for change.

To circumvent entrenched interests, however, USDA will need to do more. A polite request in the President's 1985 budget and reassurances from Dr Jordan that new funding for competitive grants will not undermine the base of support to the land-grant universities are not going to soften Jamie Whitten or his constituency of frankly uncompetitive south-eastern universities. If USDA is serious about change, it will have to fight an all-out war on two fronts, one ideological, one pragmatic.

The ideological front will be the harder of the two for the department because it is unfamiliar terrain. Simply, USDA must cease to present science as something separate from agricultural policy as a whole. In a world that has perhaps forty years in which to double food production, agricultural research is much more than something to provide a better standard of living for farmers. And with the fruits of conventional applied agricultural research drying up, partly because there is only so much that better use of fertilizer can accomplish, the need to replenish the basic store of knowledge is ever greater. We have done everything we can with applied research; we now have to tackle the organism itself.

A basic understanding of plant molecular biology, and its application in genetic engineering, will also yield solutions of the main problem that preoccupies USDA, how to keep farmers in business. Genetic engineering holds the promise of reducing input costs while improving yield, thus easing the pressures that force farmers to expand to maintain income, plant fencerow to fencerow, till marginal and erodable land and produce evergreater local surpluses that only increase the cost of price supports.

On the pragmatic front, USDA - and research scientists must play the political game. They should take a lesson from the director of USDA's in-house Agricultural Research Service (ARS), who has succeeded, against all political odds, in closing six of its most inefficient field laboratories. ARS, no less than the land-grant funds, has been the victim of congressional politics based on the principle of bringing home the goodies for the home district. Many of its regional laboratories are inefficient, underutilized or directed to outdated problems, none of which worries the congressmen in whose district they lie. ARS's administrator, Dr Terry Kinney, has worked with local politicians and industry in what should be an obvious approach, but unfortunately is not: he combines reassurances that any money saved through closing a laboratory will remain in the region with an unabashed effort to find a local constituency that will back a new research initiative. A congressman faced with competing demands from two separate constituencies is sure to look deeper into their relative merits than one faced with a single constituency fighting the loss of some prize for which he himself fought long and hard.

USDA, if it is serious about competitive grants, can do the same with the scientific community. Many states - particularly the larger ones - have first-rate land-grant universities that would benefit from increased peer-reviewed support for agricultural research; private universities can make a legitimate claim on their state's elected representatives as well. It is time for USDA to put its not inconsiderable weight where its mouth is.

\section{Set graduates free}

\section{Reform of British public support for graduate students is overdue; a chance has arisen.}

AMONG; systems of higher education, the British stands out in one striking respect - a large proportion of those reading for higher degrees are supported financially by the government. Over the decades since the Second World War, this has helped to increase the output of doctoral graduates, especially in the sciences. For most of that time, there has been general applause for the way in which public support for graduate students has helped to sustain the volume of research as such and to ensure that those drawn into this expanding enterprise include some of the most able. Only recently has the system attracted criticism of importance - first, three years ago, the suspicion based on performance at different universities that many graduate students embark too lightly on a research career and then 100 casually drop out, or that many graduate studentships are too of ten mistaken for lifelong careers. More recently, as funds have shrunk, more particular complaints have arisen. Geophysicists at the universities have, for example, taken to complaining that too few studentships are awarded to young people in that field. This is one of the issues certain to be provoked by the invitation from the Natural Environment Research Council for comments on its handling of studentships (see page 661).

It must be hoped that comments will be more radical than that. The majority of graduate studentships are at present awarded on a quota system, so many for particular university departments, so many (fewer) for others. Although the Science and Engineering Research Council has a kind of reserve by means of which bright people unlucky in the competition for allotted places can be rescued, there can be no assurance that the system is as equitable as it is intended to be, while the pattern of research followed by graduate students is determined less by their own interests than by the decisions of the research councils. The remedy will not be found by a different distribution of studentships but only by more radical revisions of the system. Abolition of the quota system alt ogether would be better. Allowing would-be graduate students some say in which universities should have how many of them would be another step towards the pattern of diversity which most of those in charge now believe should be encouraged. 